\title{
Muddy conditions reduce hygiene and lying time in dairy cattle and increase time spent on concrete
}

\author{
Jennifer M. Chen, ${ }^{*}$ Carolyn L. Stull, $†$ David N. Ledgerwood, ${ }^{*}$ and Cassandra B. Tucker ${ }^{* 1}$ \\ *Department of Animal Science, and \\ †School of Veterinary Medicine, University of California, Davis, 95616
}

\begin{abstract}
Dairy cattle spend less time lying and show signs of increased stress when housed in rainy and windy conditions, but no work has separated the effects of exposure to inclement weather from muddy conditions underfoot. Our objective was to evaluate the effects of muddy conditions alone on lying behavior, hygiene, and physiological responses. We housed pairs of pregnant, nonlactating dairy cattle $(\mathrm{n}=12 ; 6$ primigravid heifers, 6 multiparous cows) in enclosed pens with dirt floors and a concrete feed apron. Cattle were exposed to 3 levels of soil moisture: 90 (dry), 74 (muddy), or 67\% (very muddy) dry matter for $5 \mathrm{~d}$ each in a replicated $3 \times 3$ Latin square design. Lying time was measured on all days with data loggers, and lying locations and postures were recorded on the final day of each treatment. Before and after each treatment, blood samples were collected, and the percentage of dirty surface area was measured on the udder, hind leg, and side of each animal. Cattle spent less time lying down in muddier conditions, especially in the first $24 \mathrm{~h}$ of exposure, when cows and heifers spent only 3.2 and $5.8 \mathrm{~h}$, respectively, lying down in the muddiest treatment compared with 12.5 and $12.7 \mathrm{~h}$ on dry soil. When the soil was dry, cattle never chose to lie down on concrete, but in muddier conditions they spent a greater proportion of their lying time on concrete (mean \pm SE: $56 \pm 14$ and $10 \pm$ $8 \%$ in the very muddy and muddy treatments, respectively). The shift in lying location was more marked for heifers, and all 6 spent $\geq 87 \%$ of their lying time on concrete in the muddiest treatment. When cattle chose to lie down on wetter soil, they limited the surface area exposed to their surroundings by tucking their legs beneath their bodies (mean \pm SE: $30 \pm 11,15 \pm 4$, and 5 $\pm 2 \%$ of lying observations in the very muddy, muddy, and dry treatments, respectively). Despite cattle spending less time on wetter soil, all 3 measured body parts
\end{abstract}

Received September 7, 2016.

Accepted October 27, 2016.

${ }^{1}$ Corresponding author: cbtucker@ucdavis.edu became dirtier in muddier conditions (1.4-, 1.6-, and 1.8-fold more on the leg, udder, and side, respectively, in the muddiest compared with the driest treatment). In addition, higher soil moisture levels resulted in greater reductions in white blood cell counts relative to baseline levels $\left(-0.95,-0.43\right.$, and $0.34 \times 10^{9} / \mathrm{L}$ relative to baseline levels in the very muddy, muddy, and dry treatments). Muddy conditions, even in the absence of wind or rain, are aversive for cattle and have negative implications for their welfare.

Key words: behavior, hygiene, lying, moisture

\section{INTRODUCTION}

In drylot systems, cattle are kept in open dirt corrals with a concrete pad in front of the feed bunk. Nationwide, drylots house $18 \%$ of all lactating and $37 \%$ of all dry cows (USDA, 2010), and 1 in 5 operations house pregnant heifers using this system (USDA, 2016). Compared with housing systems that have primarily concrete flooring, systems that have dirt surfaces may provide advantages for animal welfare. For example, the United States Department of Agriculture reported lower prevalence of hock lesions and lameness in drylots than in freestalls and tiestalls (USDA, 2010).

However, a potential disadvantage of drylots is that cattle are less sheltered from the elements than with indoor housing. Exposure to wet weather and muddy conditions underfoot can negatively affect production. Milk yield is reduced in months with greater precipitation in California, particularly in open corral systems (Stull et al., 2008). Decreased productivity may, in part, be mediated by the additional energy requirements associated with thermoregulation in wet environments (Degen and Young, 1993) or walking in mud (Dijkman and Lawrence, 1997). Furthermore, feed intake in dairy cattle is likely to be reduced in muddy conditions (Cornell Net Carbohydrate and Protein System model; Fox and Tylutki, 1998). Therefore, cattle may increase fat metabolism to meet their energy requirements, as evidenced by higher circulating nonesterified fatty acid (NEFA) levels in inclement weather (Tucker et al., 2007). 
Exposure to mud also has implications for cattle health. Farms with muddier corrals have more digital dermatitis (Rodríguez-Lainz et al., 1996), and moisture reduces claw hardness and increases the risk of lameness (Fitzgerald et al., 2000; Borderas et al., 2004). In addition, studies conducted in winter have recorded poorer hygiene scores in muddier conditions (Muller et al., 1996; Fisher et al., 2003). Poor udder hygiene is associated with higher SCS (Reneau et al., 2005) and IMI (Schreiner and Ruegg, 2003), and hygiene scoring is commonly used in welfare assessments (Welfare Quality, 2009; National Milk Producers Federation, 2013). In drylots, a higher proportion of cows were very dirty $(22 \%)$ compared with cows in freestalls and tiestalls (10 and 16\%, respectively; USDA, 2010). Interestingly, however, lower prevalence of mastitis was recorded in drylots (11\%) than in freestalls or tiestalls (18 and 19\%, respectively; USDA, 2010).

In addition to affecting health and production, exposure to wet winter conditions influences lying behavior. Research has shown that cattle are motivated to lie down for approximately half of the day (Jensen et al., 2005), and when faced with a tradeoff between feeding and lying, they prioritize the latter (Metz, 1985; Munksgaard et al., 2005). Lying time is reduced when cows are exposed to rain and wind (Tucker et al., 2007; Webster et al., 2008; Schütz et al., 2010) and when sawdust bedding is wetter (Fregonesi et al., 2007; Reich et al., 2010) compared with when housed indoors and provided with dry material, respectively. In addition, in inclement weather, cattle lie with their legs tucked beneath their bodies, which may help reduce heat loss (Tucker et al., 2007). Perhaps related to reduced lying time, exposure to wind and rain results in a cascade of physiological stress responses, including increased plasma cortisol concentrations (Tucker et al., 2007; Webster et al., 2008) and fecal glucocorticoid metabolites (Fisher et al., 2003; Tucker et al., 2007; Webster et al., 2008) as well as lower white blood cell (WBC) counts (Webster et al., 2008).

Although previous studies have examined cattle responses to wet weather, little is known about the effects of exposure to muddy surfaces alone, and no studies have systematically varied the level of soil moisture. Our objective was to evaluate the effects of muddy conditions, separate from rain and wind, on the behavioral and physiological responses of dairy cattle. We hypothesized that greater levels of soil moisture (i.e., increased muddiness) would adversely affect lying behavior, thermoregulation, hygiene, and stress levels. Specifically, we predicted that muddier conditions would result in reduced lying time and the surface area cattle exposed to the mud. We also predicted that body temperature, DMI, cleanliness, and WBC counts would be reduced in muddier conditions, whereas plasma cortisol and NEFA concentrations would increase. In addition, we predicted that the responses of multiparous cows would be greater in magnitude than those of primigravid heifers due to differences in BW and udder size, because these characteristics may affect surface area exposed to mud, heat exchange, and willingness to lie down on concrete.

\section{MATERIALS AND METHODS}

\section{Animals and Housing}

The study was conducted at the University of California Davis (UC Davis), with all procedures approved by the Institutional Animal Use and Care Committee. Twelve pregnant, nonlactating Holstein-Friesian dairy cattle were transported in 2 cohorts from the UC Davis dairy herd to enclosures at the UC Davis feedlot. Six cattle were primigravid (heifers), and 6 were multiparous (cows; mean $\pm \mathrm{SD}$ parity $=2.2 \pm 0.8$, range $=1$ to 3 ). Bodyweight and BCS (1 to 5 scale; Ferguson et al., 1994) were recorded 3 times during the experiment and averaged $537 \pm 68 \mathrm{~kg}$ and $3.8 \pm 0($ mean $\pm \mathrm{SD}$ ), respectively, for the heifers and $700 \pm 97 \mathrm{~kg}$ and $3.3 \pm$ 0.3 for the cows.

Cattle were paired ( 1 heifer and 1 cow), and each pair was randomly assigned to 1 of 3 enclosures. Each enclosure consisted of a dome-like structure with a white cover (Intertape Polymer Group, Montreal, QC, Canada) and a ventilation system. Within each enclosure (11 $\mathrm{m}$ wide $\times 22 \mathrm{~m}$ long), a pen ( $2.4 \mathrm{~m}$ wide $\times 18 \mathrm{~m}$ long) was created using portable livestock fencing (Powder River, Provo, UT). A concrete pad (2.9 m long, $16.1 \%$ of the total pen area) abutted the feed bunk at one end. The remaining soil-floored area was demarcated into 5 sections of $2.9 \mathrm{~m}$ length (each $16.1 \%$ of the total pen area) and 1 section of $0.6 \mathrm{~m}$ length (3.3\% of the total pen area) containing the water trough. Cattle had ad libitum access to a ration consisting of $51 \%$ oat hay, $26 \%$ alfalfa, $15 \%$ almond hulls, and $8 \%$ commercial dry cow pellets (as fed; Associated Feed and Supply Co., Turlock, CA), fed daily at 0900 and $1700 \mathrm{~h}$.

\section{Treatments}

The floor was lined with 1.1-mm EPDM rubber (45mil Tetra Pond, Blacksburg, VA) and covered with dry soil (90\% DM; dry treatment). A slurry (19.5\% DM) of urine, feces, and water from the UC Davis dairy facility was added to create 2 additional soil treatments with $74 \%$ DM (muddy treatment; Figure 1) and $67 \%$ DM (very muddy treatment). Each treatment period was 5 consecutive d (with 24-h periods beginning and 


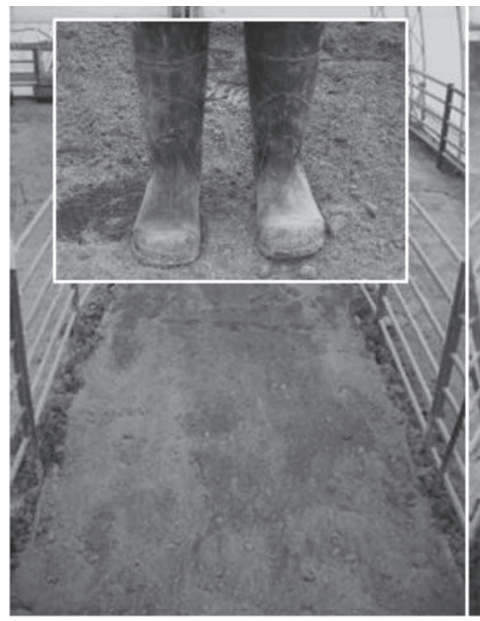

Dry $(90)$

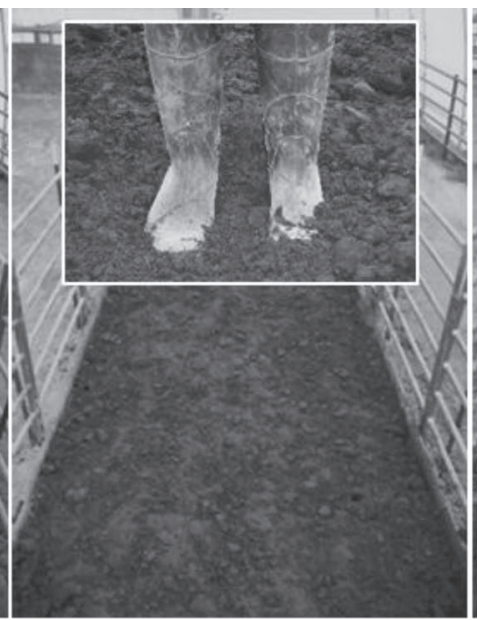

Muddy (74)

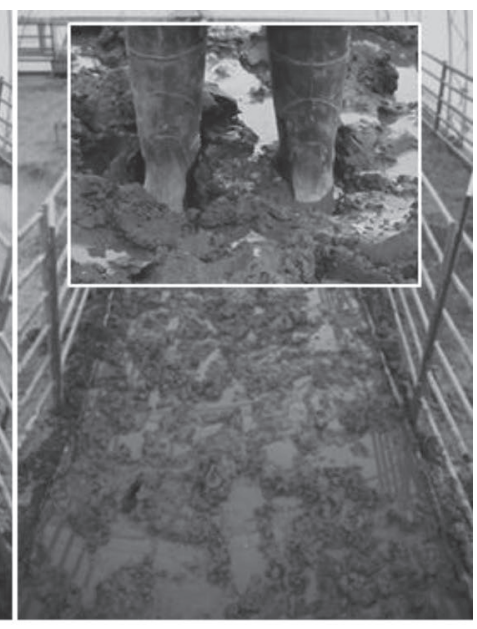

Very muddy (67)

Soil moisture level (\% DM)

Figure 1. Three levels of soil moisture were compared. The insets show a magnified view of a researcher's boots while standing on each soil treatment.

ending at $0930 \mathrm{~h}$ ), and all pairs of cattle received all 3 treatments in a replicated $3 \times 3$ Latin square design. Each cohort of 6 cattle was housed in a separate straw-bedded enclosure (rest pen, $40 \mathrm{~m}^{2}$ /animal) for $3 \mathrm{~d}$ of acclimation before the first treatment and for $5 \mathrm{~d}$ of rest between treatments (28 d total/animal). During the rest period, the concrete pads were scraped clean and the soil treatments were moved among enclosures. As urine and manure accumulated during the treatment periods, the soil depth and moisture were adjusted before each treatment by adding slurry or dry soil. These adjustments were based on soil moisture and depth measurements recorded on $\mathrm{d} 1$ and 3 of each treatment period and $\mathrm{d} 1$ of the rest period using 3 samples/d collected from each of the $2.4 \times 2.9 \mathrm{~m}$ soil sections (excluding the area around the water trough).

\section{Environmental Measures}

Air temperature $(\mathbf{T})$ and relative humidity $(\mathbf{R H})$ were recorded at 5 -min intervals using loggers (HOBO H08; Onset Computer Corp., Pocasset, MA). Temperature-humidity index (THI) was calculated according to the following equation from Kelly and Bond (1971):

$$
\begin{aligned}
\mathrm{THI}=(1.8 \times & \mathrm{T}+32)-[0.55-(0.0055 \times \mathrm{RH}) \\
& \times(1.8 \times \mathrm{T}-26)] .
\end{aligned}
$$

For the second cohort of cattle, soil temperature was recorded at 10-min intervals using a logger (HOBO U12-015; Onset Computer Corp.) buried in the center of 1 enclosure/d and moved to a different enclosure at $0930 \mathrm{~h}$.

\section{Cattle Measures}

On the day before each treatment began and at the conclusion, cattle were restrained in headlocks in the rest pen. During this time, lying and body temperature loggers were attached or removed, hygiene was scored, and blood samples were collected.

Lying Loggers. Lying behavior was recorded $24 \mathrm{~h} / \mathrm{d}$ at 30-s intervals by loggers (HOBO Pendant G; Onset Computer Corp.). Each logger was placed in a canvas pouch and affixed to the lateral side of a hind leg above the metatarsophalangeal joint. The logger was switched to the opposite leg between treatments, and the order was balanced among cattle. The $\mathrm{x}-\mathrm{y}$ - and z-axes of the logger were positioned parallel, perpendicular, and parallel to the ground, respectively, and were oriented cranially, dorsally, and medially, respectively. The pouch was attached to the leg with cohesive bandage (Vetrap; $3 \mathrm{M}$ Products, St. Paul, MN) using the procedures described by Ledgerwood et al. (2010). To correct short, possibly erroneous logger readings, we used Microsoft Excel macros (Microsoft Corp., Redmond, WA) to convert all occurrences of 2 consecutive, isolated readings of lying or standing to the preceding behavior (Ledgerwood et al., 2010). Lying events that began and ended in different 24 -h periods were excluded. Among cattle, these events ranged from 0 to $13 \mathrm{~min} / 24 \mathrm{~h}$.

Body Temperature Loggers. Body temperature was recorded intravaginally $24 \mathrm{~h} / \mathrm{d}$ at 10-min intervals 
Table 1. Definitions used to evaluate the behavioral responses of nonlactating cattle to varying levels of soil moisture

\begin{tabular}{ll}
\hline Behavior & Definition \\
\hline $\begin{array}{l}\text { Location in the pen } \\
\text { Lying }\end{array}$ & Section $^{1}$ of the pen in which the left front hoof was present \\
$\begin{array}{l}\text { Postures while lying } \\
\text { Lateral }\end{array}$ & Weink in contact with the ground \\
Sternal & Weight borne on the sternum \\
Leg positions while lying in a sternal posture & Leg (either exposed ${ }^{2}$ or underside ${ }^{3}$ ) bent at the knee and the hoof pointed back toward \\
Front leg bent & the body \\
Exposed front leg touching & Leg bent and no visible gap between the metacarpus and the fetlock joint \\
Exposed hind leg bent & Leg bent at $<90^{\circ}$ angle \\
Exposed hind leg touching & Metatarsus in contact with the trunk or udder \\
Underside hind leg visible & Metatarsus visible above the fetlock joint of the underside leg \\
Feeding & Upright with the poll past the overhead feed rail \\
Standing & Upright, excluding feeding \\
\hline
\end{tabular}

${ }^{1}$ Each long, narrow pen was demarcated width-wise into 7 sections. Six equal-sized sections each comprised $16.1 \%$ of the total area $(5$ with a soil surface and 1 with concrete and a feed bunk), and 1 section comprised $3.3 \%$ of the total area (with a soil surface and a water trough).

${ }^{2}$ Exposed legs were those on the side of the body bearing less weight.

${ }^{3}$ Underside legs were those on the side of the body bearing more weight.

with loggers (Minilog12-TX; accuracy $\pm 0.1^{\circ} \mathrm{C}$; resolution $\pm 0.015^{\circ} \mathrm{C} ; 1.6 \mathrm{~cm}$ diameter $\times 7 \mathrm{~cm}$ length; Vemco Ltd., Bedford, NS, Canada) attached to shortened, hormone-free controlled internal drug-release inserts (InterAg, Hamilton, New Zealand).

Hygiene. Hygiene was quantified on 3 body locations by placing wire grids against the cattle and counting the number of grid squares in which soil was visible (similar to Tucker et al., 2001). A $14 \times 12$ (width $\times$ height) grid of $25 \mathrm{~cm}^{2}$ squares was used to score the right side of the body $\left(4,200 \mathrm{~cm}^{2}\right.$ total), and $6 \times 18$ and $7 \times 7$ grids of $6.25 \mathrm{~cm}^{2}$ squares were used on the right hind leg above the hock $\left(675 \mathrm{~cm}^{2}\right.$ total $)$ and the rear aspect of the udder $\left(306.25 \mathrm{~cm}^{2}\right.$ total $)$, respectively. This measure was recorded by 1 observer with intra-observer reliability of $r=0.971$ (Pearson correlation). The increase in the percentage of dirty surface area resulting from exposure to the treatments was determined by calculating the difference in the number of dirty grid squares from the beginning to the end of each treatment period and dividing by the total number of grid squares $(168,108$, and 49 on the side, udder, and leg, respectively). Cattle were rinsed with water between treatment periods to remove soil.

Hematological Measures. Blood samples were collected from a coccygeal vessel using 2 evacuated blood collection tubes (BD Vacutainer; Becton, Dickinson and Co., Franklin Lakes, NJ): 1 containing EDTA for complete blood count $(4 \mathrm{~mL})$ and 1 with no anticoagulant for plasma cortisol and NEFA levels $(6 \mathrm{~mL})$. Samples were transported on ice to the hematology laboratory of the UC Davis Veterinary Medicine Teaching Hospital for analysis, where they were centrifuged (Marathon 21000R; Fisher Scientific, Pittsburgh, PA) at 3,000 $\times g$ for $10 \mathrm{~min}$ at $25^{\circ} \mathrm{C}$. Whole blood was used for determi- nation of WBC count and leukocyte differential using an automated cell counter (ADVIA 120 Hematology System; Siemens Healthcare Diagnostics Inc., Malvern, PA) and standard laboratory techniques (Heckner et al., 1988). Determination of NEFA levels was performed by an automated analyzer (Roche Hitachi 912 Chemistry Analyzer; Roche Diagnostics, Indianapolis, IN) using the NEFA-HR(2) method (Wako Diagnostics, Mountain View, CA). Plasma cortisol levels were measured using an automated chemiluminescent assay (Immulite 2000; Siemens Healthcare Diagnostics Inc.).

Behavioral Observations. In the final $24 \mathrm{~h}$ of each treatment period, 5 observers recorded behavioral responses (Table 1) using instantaneous scan sampling at 10-min intervals. Interobserver reliability based on percentage agreement ranged from 97 to $100 \%$ for all behaviors.

Feed Intake. Feed intake for each pair of cattle was assessed by weighing refusals daily at $0900 \mathrm{~h}$ and subtracting these from the total weight of feed delivered in the previous 24 -h period. All weights were converted to a DM basis using samples that were dried in a $100^{\circ} \mathrm{C}$ forced-air oven.

\section{Statistical Analysis}

Missing Data. Body temperature data were missing for 2 cows (all $5 \mathrm{~d}$ for one and $\mathrm{d} 4$ and 5 for the other) in the very muddy treatment and 1 cow in the muddy treatment (all $5 \mathrm{~d}$ ). Lying behavior from the data logger was missing for 1 heifer in the dry treatment (all $5 \mathrm{~d}$ ). Data for ambient $\mathrm{T}$ and $\mathrm{RH}$ (and thus THI) were lost for $\mathrm{d} 1$ and 2 for the first cohort in the muddy and very muddy treatments. 
Statistical Models. Means and SE were generated using PROC SUMMARY (SAS software version 9.4; SAS Institute Inc., 2014), and statistical models were constructed using PROC MIXED. The fit of the data to the assumption of normality was determined by both visual inspection of the residuals and by the ShapiroWilk statistic $(\geq 0.95)$. Appropriate covariance structures were selected based on the lowest Akaike information criterion value. All models used the containment method to estimate degrees of freedom. Significant effects were defined as $P<0.05$, and tendencies were considered $P<0.10$.

The measures of environmental conditions were 24-h average and minimum T, RH, THI, and soil temperature. Data were averaged within each treatment period for each pair of cattle, resulting in a total of 6 observations per treatment for T, RH, and THI and 3 observations per treatment for soil temperature, which was measured only for the second cohort. Each environmental measure was evaluated using a model with a variance components covariance structure, a fixed term for treatment as a continuous variable $(\mathrm{df}=1)$, and a random term for pair of cattle.

For the cattle-based measures, we had specific hypotheses that cows and heifers would respond differently to the treatments. Therefore, we conducted analyses using the individual animal as the experimental unit (n $=12$ ), which was included in each model as a random term. The exception was DMI, which was measured at the pen level, and models with this variable used pair of cattle as the random term. Changes in dirtiness on the side, udder, and leg, and changes in NEFA, plasma cortisol, WBC count, and neutrophil:lymphocyte ratio were evaluated based on the differences in values between the start and end of each treatment period. Body temperature, DMI, and all behavioral responses were evaluated for each $24 \mathrm{~h}$. Daily lying behavior (total time, number of bouts, and average bout length), body temperature (average, minimum, and maximum), and DMI were averaged for the $5 \mathrm{~d}$ per treatment period to evaluate overall treatment and parity effects. The amount of time cattle spent lying, feeding, and standing without feeding, the proportion of total, lying, and standing time spent on concrete or soil, and leg positions while lying on soil were recorded only on d 5 of each treatment period. For each measure, a model was constructed with a variance components covariance structure and fixed terms for parity (categorized as 0 vs. $\geq 1, \mathrm{df}=1)$, treatment as a continuous variable ( $\mathrm{df}$ $=1)$, and a parity $\times$ treatment interaction $(\mathrm{df}=1)$. To evaluate changes over time in lying behavior, body temperature, and DMI, separate models were constructed using a first-order autoregressive covariance structure and additional fixed terms for day as a continuous variable $(\mathrm{df}=1)$ and a treatment $\times$ day interaction $(\mathrm{df}=$ 1). For the analysis over time, average lying bout length was Winsorized at the 5th and 95th percentiles to meet the assumption of normality.

\section{RESULTS}

\section{Environmental Measures}

Average soil DM (mean $\pm \mathrm{SD}$ ) in the dry, muddy, and very muddy treatments was $90 \pm 4,74 \pm 3$, and $67 \pm 4 \%$, respectively, and average soil depth was 10.4 $\pm 3.0,11.9 \pm 3.5$, and $11.3 \pm 3.3 \mathrm{~cm}$, respectively. We observed no treatment differences in soil temperature $\left(F_{1,5} \leq 0.8, P \geq 0.406\right.$; Table 2$)$ or in T, RH, or THI $\left(F_{1,11} \leq 0.4, P \geq 0.568\right)$.

Table 2. Mean \pm SE environmental conditions when nonlactating cattle $(\mathrm{n}=12)$ were exposed to 3 levels of soil moisture for $5 \mathrm{~d}$ in enclosures

\begin{tabular}{|c|c|c|c|}
\hline \multirow[b]{2}{*}{ Environmental variable } & \multicolumn{3}{|c|}{ Soil moisture level (\% DM) } \\
\hline & Dry $(90)$ & Muddy (74) & Very muddy (67) \\
\hline \multicolumn{4}{|l|}{ Air temperature $\left(\mathrm{T},{ }^{\circ} \mathrm{C}\right)$} \\
\hline 24 -h mean & $14.3 \pm 0.7$ & $14.3 \pm 0.8$ & $14.2 \pm 0.7$ \\
\hline 24-h minimum & $6.6 \pm 0.6$ & $6.6 \pm 0.5$ & $6.6 \pm 0.5$ \\
\hline \multicolumn{4}{|c|}{ Relative humidity (RH, \%) } \\
\hline 24-h mean & $59 \pm 2$ & $60 \pm 3$ & $61 \pm 3$ \\
\hline 24-h minimum & $32 \pm 2$ & $32 \pm 3$ & $33 \pm 3$ \\
\hline \multicolumn{4}{|c|}{ Temperature-humidity index (THI) } \\
\hline $24-\mathrm{h}$ mean & $57 \pm 1$ & $57 \pm 1$ & $57 \pm 1$ \\
\hline 24-h minimum & $45 \pm 1$ & $45 \pm 1$ & $45 \pm 1$ \\
\hline \multicolumn{4}{|l|}{ Soil temperature ${ }^{1}\left({ }^{\circ} \mathrm{C}\right)$} \\
\hline 24-h mean & $15.3 \pm 2.0$ & $14.9 \pm 0.3$ & $13.7 \pm 0.7$ \\
\hline 24-h minimum & $11.7 \pm 2.3$ & $11.2 \pm 0.8$ & $11.3 \pm 1.1$ \\
\hline
\end{tabular}

${ }^{1}$ Recorded during data collection for only 3 pairs of cattle. 
Table 3. Mean \pm SE responses of nonlactating cattle $(n=12)$ before and after ${ }^{1}$ exposure to 3 levels of soil moisture for $5 \mathrm{~d}$ in enclosures

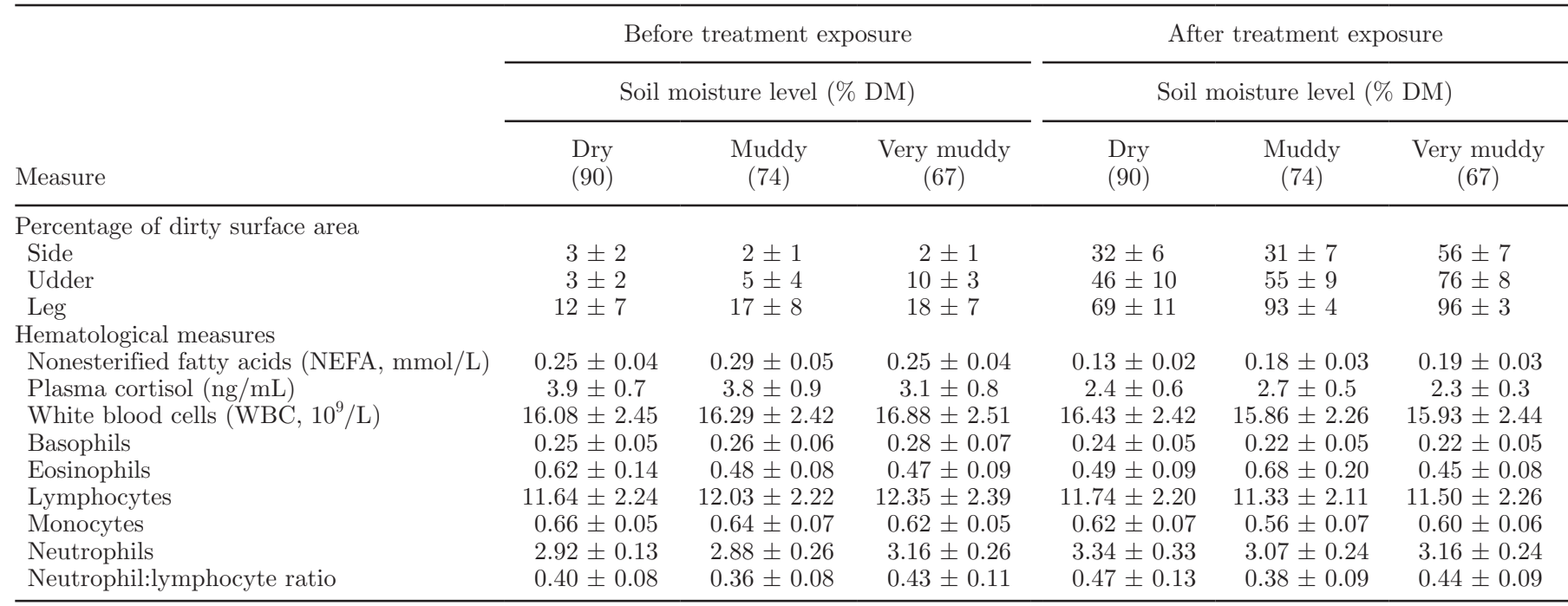

${ }^{1}$ Values are shown at the start and end of each 5-d treatment period for descriptive purposes. Treatments were applied within animal in a crossover design. The effects of treatment, parity ( 0 vs. $\geq 1$ ), and their interaction were evaluated based on the changes in each response from start to end of treatment.

\section{Hygiene}

The percentage of dirty surface area on the cattle increased between the start and end of all treatments. As soil moisture increased, so did dirtiness on the side (change $=29,29$, and $53 \%$ in the dry, muddy, and very muddy treatments, respectively, $\mathrm{SE}=5,7$, and $7 \%$; $F_{1,22}=5.2, P=0.033$; Table 3 ) and udder (change $=$ 43,51 , and $67 \%$, respectively; $\mathrm{SE}=10,10$, and $8 \%$; $\left.F_{1,22}=5.8, P=0.024\right)$. The leg tended to show this pattern as well (change $=57,76$, and $78 \%$, respectively, $\mathrm{SE}=11,8$, and $\left.8 \% ; F_{1,22}=3.1, P=0.091\right)$. We observed no effects of parity and no parity $\times$ treatment interactions $\left(F_{1,22} \leq 2.4, P \geq 0.140\right)$.

\section{Behavioral Measures}

Lying Loggers. In muddier conditions, cattle spent less time lying (dry, muddy, and very muddy treatments $=12.6,11.6$, and $9.0 \mathrm{~h} / 24 \mathrm{~h}$, respectively, $\mathrm{SE}=$ $0.6,0.5$, and $\left.0.6 \mathrm{~h} / 24 \mathrm{~h} ; F_{1,21}=35.2, P<0.001\right)$. This effect was most pronounced at the beginning of the treatment period (treatment $\times$ day interaction $F_{1,159}$ $=16.4, P<0.001$; Figure 2A, B), and lying increased over time (day $F_{1,159}=21.3, P<0.001$ ). In addition, the mud-related reduction in lying time was greater for cows than for heifers (parity $\times$ treatment interaction $\left.F_{1,21}=6.0, P=0.023\right)$, and cows spent less time lying overall than heifers ( 10.3 vs. $11.8 \mathrm{~h} / 24 \mathrm{~h}$, respectively, $\mathrm{SE}=0.7$ vs. $\left.0.4 \mathrm{~h} / 24 \mathrm{~h} ; F_{1,21}=7.9, P=0.011\right)$.
The patterns for lying time were driven primarily by the number of lying bouts. In muddier conditions, cattle had fewer lying bouts (dry, muddy, and very muddy treatments $=9.7,7.6$, and 5.8 bouts $/ \mathrm{d}$, respectively, $\mathrm{SE}$ $=1.0,0.8$, and 1.0 bouts $/ \mathrm{d} ; F_{1,21}=56.3, P<0.001$ ). This effect was most pronounced at the beginning of the treatment period (treatment $\times$ day interaction $F_{1,159}=$ $9.2, P=0.003$; Figure 2C, D), and the number of lying bouts increased over time (day $F_{1,159}=9.9, P=0.002$ ). Cows had fewer lying bouts overall than heifers (5.6 vs. 9.8 bouts/d, respectively, $\mathrm{SE}=0.7$ bouts $/ \mathrm{d} ; F_{1,21}=$ 4.8, $P=0.039)$, but we observed no parity $\times$ treatment interaction $\left(F_{1,21}=1.2, P=0.286\right)$.

In muddier conditions, cattle had longer lying bouts overall (dry, muddy, and very muddy treatments $=88$, 105 , and $117 \mathrm{~min}$, respectively, $\mathrm{SE}=8.6,9.5$, and 13.8 $\left.\min ; F_{1,21}=13.1, P=0.002\right)$. This effect became apparent after the first day of exposure (treatment $\times$ day interaction $F_{1,159}=3.9, P=0.049$; Figure $2 \mathrm{E}, \mathrm{F}$ ), and lying bout length increased over time (day $F_{1,159}=6.5$, $P=0.012$ ). In addition, the mud-related increase in lying bout length tended to be greater for cows than for heifers (parity $\times$ treatment interaction $F_{1,21}=3.0, P$ $=0.097$ ), and cows had longer lying bouts overall than heifers (127 vs. $79 \mathrm{~min}$, respectively, $\mathrm{SE}=8.6$ vs. 5.3 $\left.\min ; F_{1,21}=6.6, P=0.018\right)$.

Final Day of Treatment. In the final 24 h of treatment, cattle spent less time lying in muddier conditions and spent more time standing without feeding (Table 4). The amount of time cattle spent feeding did not 

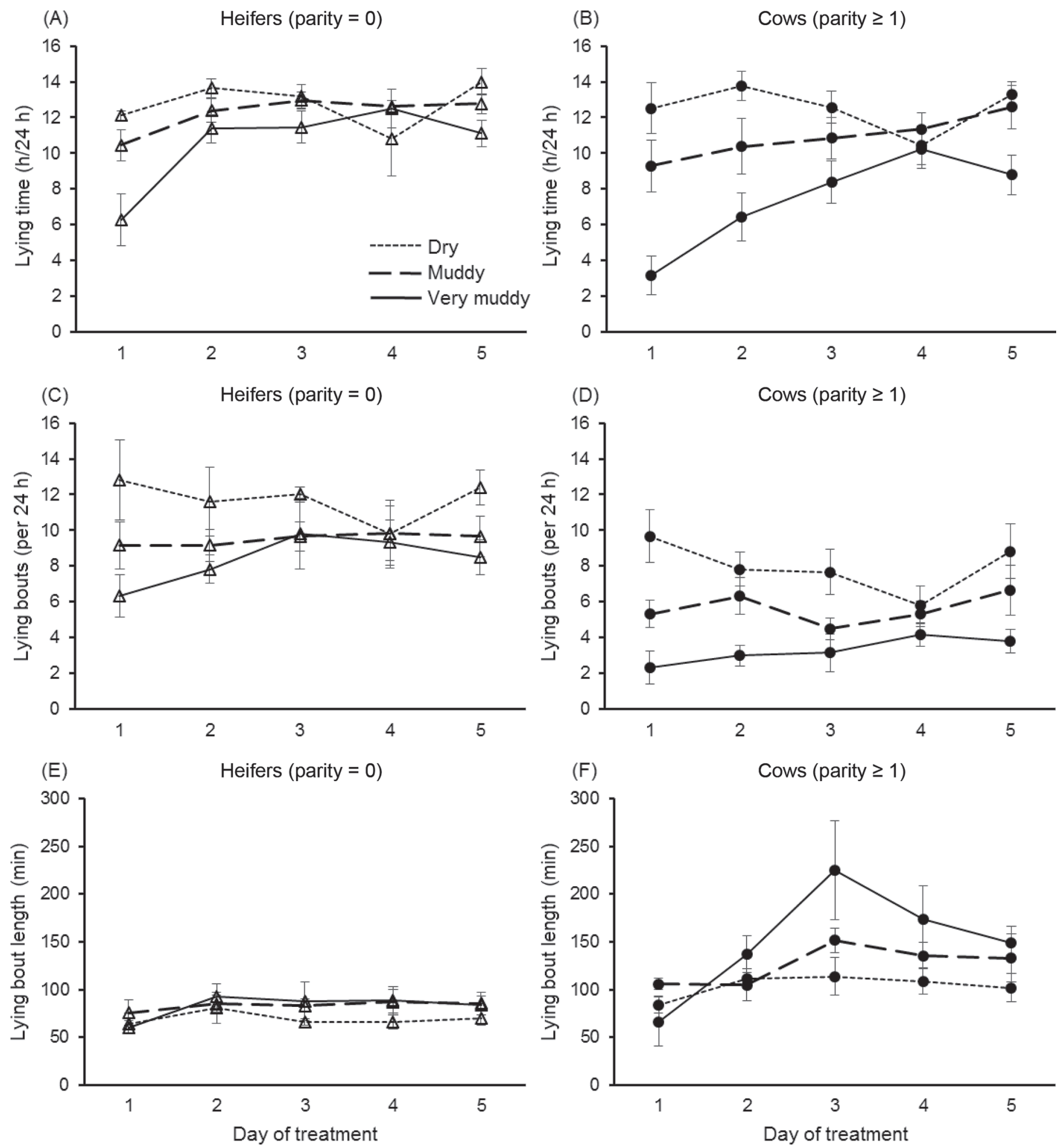

Figure 2. Mean \pm SE lying behavior when nonlactating heifers (primigravid, $\mathrm{n}=6$ ) and cows (multiparous, $\mathrm{n}=6$ ) were exposed to 3 levels of soil moisture (dry, muddy, and very muddy; 90, 74, and 67\% DM, respectively) for $5 \mathrm{~d}$ each. Shown are lying time (h/24 h) for (A) heifers and (B) cows, the number of lying bouts per $24 \mathrm{~h}$ for (C) heifers and (D) cows, and average lying bout length (min) for (E) heifers and (F) cows. 
Table 4. Mean \pm SE responses of nonlactating cattle $(n=12)$ when exposed to 3 levels of soil moisture for 5 d in enclosures ${ }^{1}$

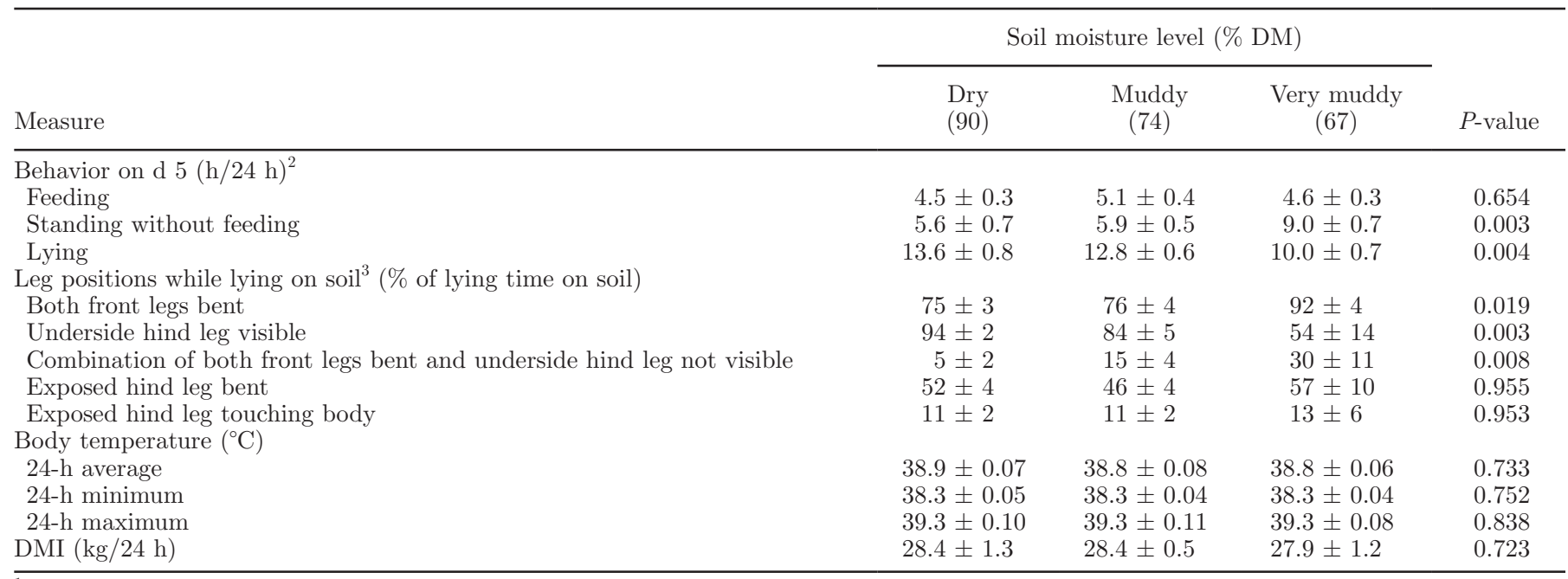

${ }^{1}$ Treatments were applied within animal in a crossover design, and $P$-values are for the effects of soil moisture level (as a continuous variable).

${ }^{2}$ Behavioral data were collected in the final $24 \mathrm{~h}$ of each 5 -d treatment period using 10-min instantaneous scan sampling.

${ }^{3}$ Leg positions were recorded when cattle were observed lying in a sternal posture on soil.

differ across levels of soil moisture, and we observed no effects of parity and no parity $\times$ treatment interactions $\left(F_{1,22} \leq 1.7, P \geq 0.207\right)$.

The average amount of time cattle spent in various areas of the pen in each treatment is depicted in Figure 3 . In muddier conditions, the proportion of time cattle spent on soil decreased and the proportion on concrete increased (treatment $F_{1,22}=23.9, P<0.001$; Figure $4 \mathrm{~A})$. This pattern was more marked for heifers than for cows (parity $\times$ treatment interaction $F_{1,22}=7.2, P=$ 0.014 ), because the former spent a greater proportion of their time on concrete (parity $F_{1,22}=9.2, P=0.006$ ).

This shift in where cattle spent their time was driven by where they chose to lie down. In the dry soil treatment, no cattle chose to lie on concrete. In muddier conditions, the proportion of time cattle spent lying on soil decreased and the proportion on concrete increased (treatment $F_{1,22}=19.3, P<0.001$; Figure $4 \mathrm{~B}$ ). This pattern was more marked for heifers than for cows (parity $\times$ treatment interaction $F_{1,22}=9.8, P=0.005$ ), because the former spent a greater proportion of their lying time on concrete (parity $F_{1,22}=12.5, P=0.002$ ). In the muddy treatment, 3 heifers (but no cows) were observed lying on concrete. In the very muddy treatment, 2 cows were observed lying on concrete, and they had the lowest lying times $(6.0$ and $6.2 \mathrm{~h} / 24 \mathrm{~h}$ compared with 8.0 to $13.0 \mathrm{~h} / 24 \mathrm{~h}$ for the others). In addition, all 6 heifers spent 87 to $100 \%$ of their lying time on concrete in the very muddy treatment. We observed no treatment differences in the proportion of standing time that cattle spent on soil or concrete (45 $\pm 4,41 \pm 4$, and $41 \pm 5 \%$ of standing time was spent on soil in the dry, muddy, and very muddy treatments, respectively; no effects of treatment or parity and no parity $\times$ treatment interaction $F_{1,22} \leq 1.1, P \geq 0.312$ ).

When cattle were lying in a sternal posture on muddier soil, they bent both front legs, held their underside hind leg beneath the body (so that it was not visible above the fetlock), or combined these leg positions more often (Table 4). We observed no effect of treatment on the position of the exposed hind leg, no effects of parity, and no parity $\times$ treatment interactions for any leg position $\left(F_{1,17} \leq 1.8, P \geq 0.196\right)$. While lying, cattle were observed in a lateral posture only $0.3 \%$ of the time across all treatments.

\section{Body Temperature}

We observed no effects of treatment on body temperature (Table 4) and no effects or interactions with parity $\left(F_{1,20} \leq 0.1, P \geq 0.757\right)$ or day $\left(F_{1,152} \leq 0.2, P\right.$ $\geq 0.641)$.

\section{DMI}

We observed no effects of treatment on DMI for pairs of cattle (Table 4) and no effects of day or treatment $\times$ day interactions $\left(F_{1,81} \leq 0.3, P \geq 0.561\right)$.

\section{Hematological Measures}

Total WBC counts decreased after exposure to muddier conditions (change $=0.34,-0.43$, and $-0.95 \times$ $10^{9} / \mathrm{L}$ in the dry, muddy, and very muddy treatments, 
respectively, $\mathrm{SE}=0.46,0.47$, and $0.46 \times 10^{9} / \mathrm{L} ; F_{1,22}$ $=5.1, P=0.035$; Table 3$)$. This finding was driven by reductions in counts of lymphocytes $(0.10,-0.70$, and $-0.85 \times 10^{9} / \mathrm{L}$, respectively, $\mathrm{SE}=0.33,0.33$, and 0.26 $\left.\times 10^{9} / \mathrm{L} ; \mathrm{F}_{1,22}=6.3, P=0.020\right)$ and basophils $(-0.01$, -0.04 , and $-0.06 \times 10^{9} / \mathrm{L}$, respectively, $\mathrm{SE}=0.01$, 0.02 , and $\left.0.2 \times 10^{9} / \mathrm{L} ; F_{1,22}=3.7, P=0.067\right)$. We observed a tendency for a parity $\times$ treatment interaction for eosinophil counts (change for heifers $=0.17,0.35$, and $-0.14 \times 10^{9} / \mathrm{L}$ in the dry, muddy, and very muddy treatments, respectively, $\mathrm{SE}=0.13,0.38$, and 0.12 $\times 10^{9} / \mathrm{L}$; change for cows $=-0.42,0.05$, and $0.09 \times$
$10^{9} / \mathrm{L}, \mathrm{SE}=0.25,0.10$, and $0.12 \times 10^{9} / \mathrm{L} ; F_{1,22}=3.3$, $P=0.083)$. We observed no other effects of treatment, parity, or parity $\times$ treatment interactions for these or the other hematological measures (monocyte and neutrophil counts, neutrophil:lymphocyte ratio, and NEFA and plasma cortisol levels; $F_{1,22} \leq 2.7, P \geq 0.114$ ).

\section{DISCUSSION}

Cattle demonstrated their aversion to wet soil in 2 ways. First, they spent less time lying down in muddier

$h / 24 h$

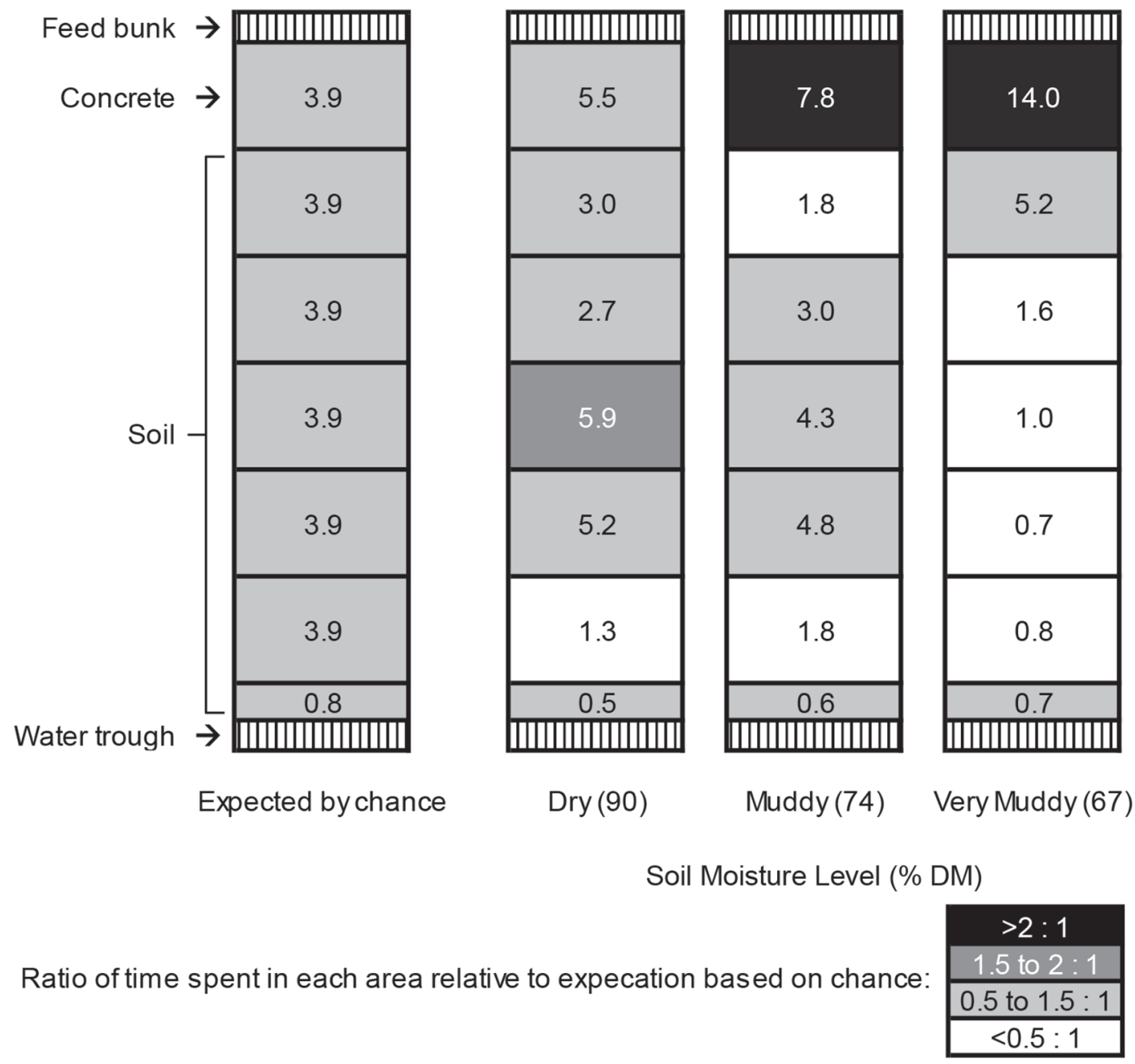

Figure 3. The amount of time nonlactating cattle $(\mathrm{n}=12)$ were expected to spend in each area of an enclosure by chance (given the dimensions), and descriptive data for the mean amount of time $(\mathrm{h} / 24 \mathrm{~h})$ they spent in each area, depending on the level of soil moisture (dry, muddy, and very muddy; 90, 74, and 67\% DM, respectively). Data were collected in the final $24 \mathrm{~h}$ of each 5-d treatment. Darker shades indicate higher ratios for the amount of time cattle spent in an area relative to what was expected by chance, categorized as <0.5:1 (less than expected by chance), 0.5 to 1.5:1 (approximately as expected by chance), 1.5 to 2:1 (greater than expected by chance), and $>2: 1$ (much greater than expected by chance). 


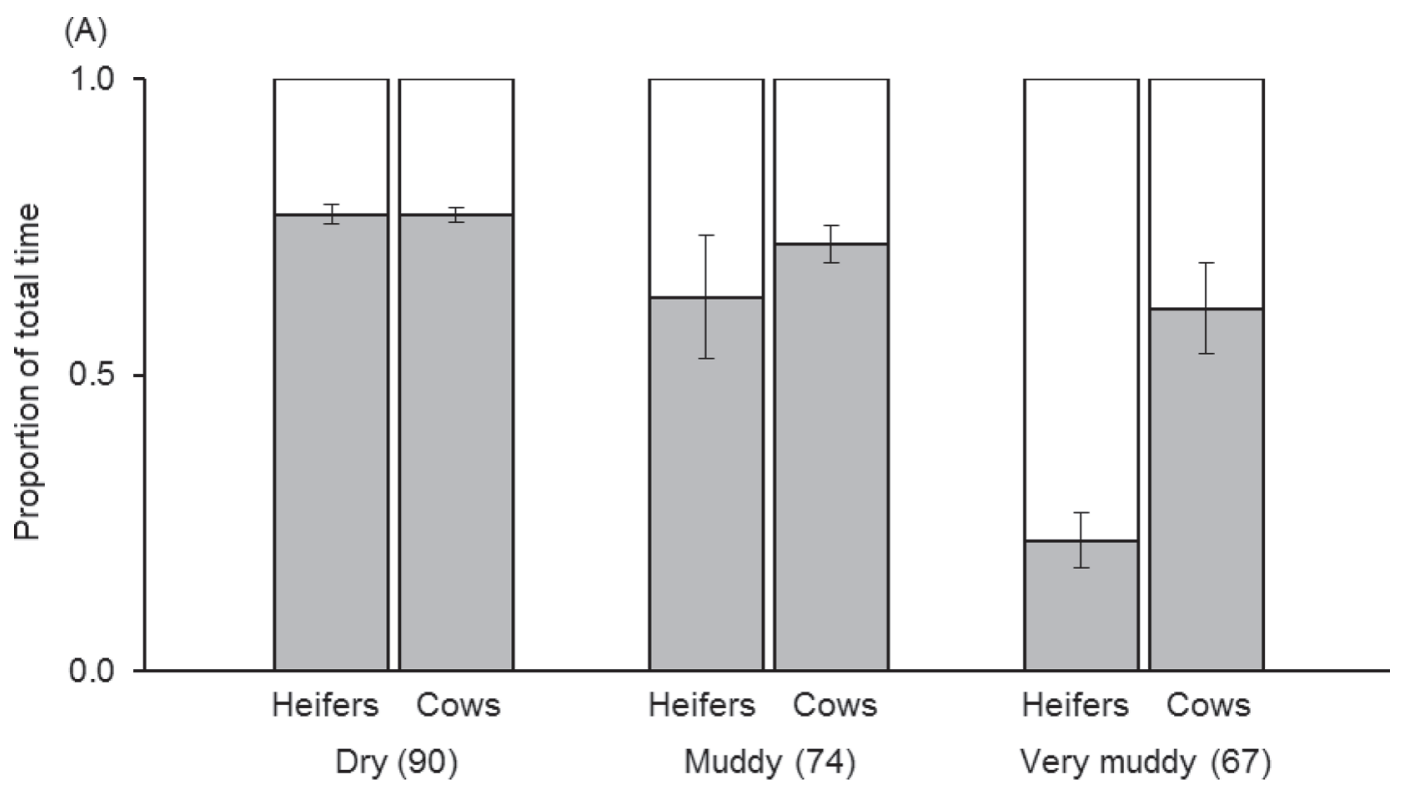

(B)

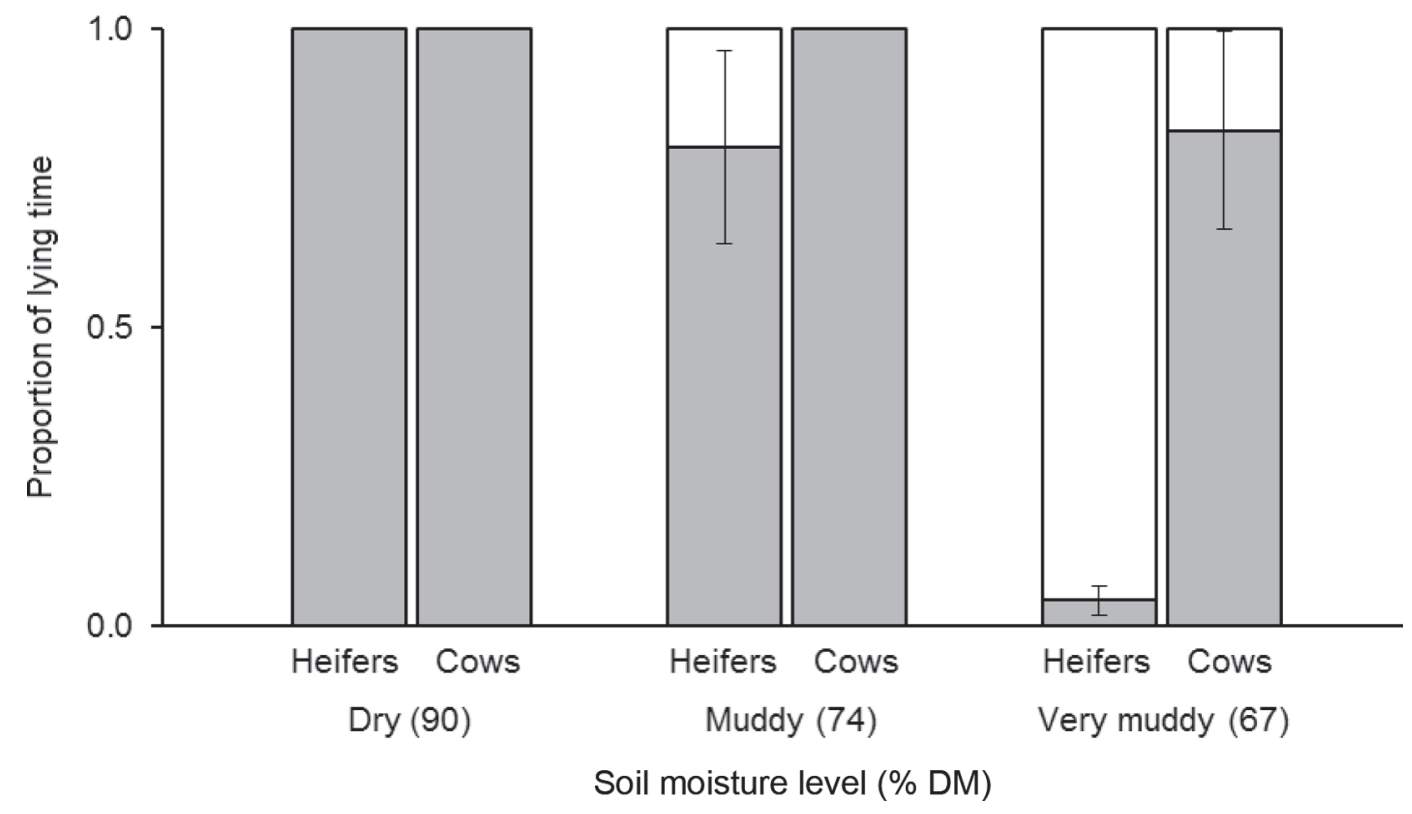

Figure 4. Mean \pm SE proportion of $(A)$ total time and (B) lying time that nonlactating heifers (primigravid, $n=6)$ and cows (multiparous, $\mathrm{n}=6$ ) spent on either soil (gray bars) or concrete (white bars) surfaces in an enclosure, depending on the level of soil moisture (dry, muddy, and very muddy; 90,74 , and $67 \%$ DM, respectively). Data were collected in the final $24 \mathrm{~h}$ of each 5 -d treatment.

conditions, a response that was greater in magnitude for cows than for heifers. When cattle chose to lie down on wetter soil, they spent a greater proportion of their lying time with their legs tucked beneath their bodies, perhaps to reduce the surface area exposed to their surroundings. Second, in muddier conditions, cattle reduced the amount of time they spent on soil and increased the amount of time they spent on concrete. This response was more marked for heifers than for cows, and the former spent the majority of their time on concrete in the muddiest treatment. In muddier conditions, although cattle spent less time on soil, the amount of dirty surface area on their sides, udders, and legs increased. Poor hygiene could present an increased risk of infection, and we also found evidence of possible immunosuppression: in muddier conditions, WBC counts showed greater reductions, driven by lower lymphocyte and basophil counts. 


\section{Lying Time and Location}

Dairy cattle are motivated to lie down for 12 to 13 $\mathrm{h} / 24 \mathrm{~h}$ (pregnant heifers in Jensen et al., 2005), and the pregnant cows and heifers in our study spent 12.5 and $12.7 \mathrm{~h} / 24 \mathrm{~h}$ lying down when the soil was dry. The literature lacks data on lying time in commercial drylot dairies, but these averages are similar to the 12 to $14 \mathrm{~h} / 24 \mathrm{~h}$ reported for lactating cows in straw yards (Fregonesi and Leaver, 2002). Shorter averages have been reported in other loose housing systems (9 to $11 \mathrm{~h} / \mathrm{d}$ for lactating cows in compost bedded packs in Endres and Barberg, 2007; $10 \mathrm{~h} / \mathrm{d}$ for nonlactating cows with rice hull bedding in Ledgerwood et al., 2010), but the reasons for these differences are unclear and warrant further research.

The response to soil moisture was dose-dependent, and cows showed more dramatic reductions in lying time than heifers did. The reductions in lying time were most pronounced in the first $24 \mathrm{~h}$ : relative to when the soil was dry, cows and heifers spent 3.2 and 1.7 fewer hours lying in the muddy treatment. In the very muddy treatment, cows and heifers spent 9.3 and 5.8 fewer hours lying, resulting in totals of only 3.2 and 5.8 h. Other studies in muddy winter conditions reported similarly low lying times ( 3.6 to $8.6 \mathrm{~h} / \mathrm{d}$ in South African drylots in Muller et al., 1996; 5.7 to $6.9 \mathrm{~h} / \mathrm{d}$ in New Zealand pasture systems in Fisher et al., 2003), although soil DM was not quantified.

Similarly, when cows were subjected to rainy winter conditions, they had extremely low lying times on wet surfaces (DM not quantified; 3.6 to $4.5 \mathrm{~h} / 24 \mathrm{~h}$ in Tucker et al., 2007; 3.4 h/16 h in Webster et al., 2008; 1.1 to $5.9 \mathrm{~h} / 22 \mathrm{~h}$ in Schütz et al., 2010). Wet sawdust bedding (27 and 36\% DM, respectively) reduced lying by 1 to $5 \mathrm{~h} / 24 \mathrm{~h}$ relative to dry bedding ( 86 and $90 \%$ $\mathrm{DM}$ ) in freestalls, resulting in total lying times of 8.8 h/24 h (Fregonesi et al., 2007) and 10.4 h/24 (Reich et al., 2010). The differences in lying times between these studies may be explained, in part, by the freestalls preventing urine and feces from exacerbating wet lying conditions or by cattle finding the texture of moist sawdust less aversive than other substrates. Some drylot dairies provide bedding during inclement weather (USDA, 2010), but research is needed to evaluate how this practice affects cattle behavior.

Similar to when cattle were kept outdoors in winter (Fisher et al., 2003), those in our study had fewer lying bouts in muddier conditions. This pattern changed with days of exposure. In the first $24 \mathrm{~h}$, lying bouts were both less frequent and shorter in muddier conditions, indicating that cattle were hesitant to lie down and remain lying on the available surfaces (wet soil and concrete). On subsequent days, cattle continued to lie down less frequently in muddier conditions, but their lying bouts lasted longer. This pattern could be due to habituation, a suggested explanation for why pastured cows showed more avoidance of walking through slurry (Phillips and Morris, 2002) than those housed indoors (Phillips and Morris, 2001). This is unlikely to be the only explanation in our study, however, as lying time was 4.6 and $2.6 \mathrm{~h}$ lower for cows and heifers, respectively, in the very muddy treatment than in the dry treatment even after $5 \mathrm{~d}$ of exposure.

Instead, as cattle spent more time in muddy conditions, they may have remained recumbent for longer periods to compensate for the initial severe deficit in lying, similar to what is observed after cattle are prevented from lying down (Metz, 1985; Bolinger et al., 1997; Jensen et al., 2004). Lying is of such importance to cattle that, when faced with a tradeoff between feeding and lying, they prioritize the latter (Metz, 1985; Munksgaard et al., 2005). Our findings support the idea that cattle are highly motivated to lie down and will do so, to an extent, even on undesirable surfaces. Between the first and last day of the muddiest treatment, we observed 3.2 and $4.7 \mathrm{~h} / 24 \mathrm{~h}$ increases in lying time for heifers and cows, respectively, similar in magnitude to the 3.0 to $5.2 \mathrm{~h} / 24 \mathrm{~h}$ increases seen across $4 \mathrm{~d}$ when cows were housed for $18 \mathrm{~h} / 24 \mathrm{~h}$ on bare concrete (Schütz and Cox, 2014). Studies have demonstrated that concrete is an undesirable lying surface that results in reduced lying time (e.g., Haley et al., 2001; Fisher et al., 2003; Rushen et al., 2007) and hesitation before lying down (Krohn and Munksgaard, 1993).

Although previous work has shown that, when given the choice, cattle prefer drier bedding (Keys et al., 1976; Fregonesi et al., 2007), our study is the first to provide evidence that wet soil is a more aversive lying surface than concrete. When the soil was dry, cattle spent $23 \%$ of their overall time on the concrete pad, but no cattle chose to lie down on this surface. The majority of their time on the concrete pad in the dry treatment was spent feeding, which comprised 19 to $21 \%$ of the time budget in all treatments, comparable to the 19 to $24 \%$ in other studies using 10-min instantaneous sampling (Endres et al., 2005; Fregonesi et al., 2007). In muddier conditions, cattle spent more time on the concrete pad both lying down and standing without feeding. In the muddiest treatment, heifers and cows spent 78 and $39 \%$ of their total time on concrete, even though it comprised only $16 \%$ of the pen area.

On hard or abrasive surfaces such as concrete, transitioning between lying and standing may be more challenging (as suggested by Haley et al., 2000). Because the cows in this study were, on average, $30 \%$ heavier than the heifers, they likely experienced greater pressure on their knees when lying down and standing up. 
This may explain why, relative to the cows, the heifers were more willing to lie down on concrete, and all 6 spent almost all (87 to 100\%) of their lying time on concrete in the muddiest conditions. Interestingly, the 2 cows that chose to lie down on concrete in the very muddy treatment were those with the lowest lying times $(6.0$ and $6.2 \mathrm{~h} / 24 \mathrm{~h}$, compared with 8.0 to $13.0 \mathrm{~h} / 24 \mathrm{~h}$ for the other 4 cows), suggesting that they found the wet soil particularly aversive. Spending more time on concrete has negative implications for welfare, because exposure to this surface can result in poorer locomotion scores and shortened stride length (Schütz and Cox, 2014) and is associated with greater prevalence of claw disorders (Vermunt and Greenough, 1996; Somers et al., 2003; Vanegas et al., 2006).

\section{Cortisol, WBC Counts, and Hygiene}

The increase in lying time across days spent in muddy conditions may explain why the predicted increases in plasma cortisol levels were not observed in this study, or when pastured cattle were housed in stand-off pens for $4 \mathrm{~d}$ (Schütz and Cox, 2014). In both studies, the greatest reductions in lying occurred in the first 24 $\mathrm{h}$ of exposure, and collecting blood samples closer to this time may have revealed changes in hypothalamicpituitary-adrenal axis activity. Other studies found that lying deprivation was associated with acute stress responses, including increased plasma cortisol concentrations (using similar or larger sample sizes, $\mathrm{n}=10$ to 16; Fisher et al., 2002; Tucker et al., 2007; Webster et al., 2008) and fecal glucocorticoid metabolites (Fisher et al., 2003; Tucker et al., 2007; Webster et al., 2008), as well as pituitary downregulation in response to a corticotropin-releasing hormone challenge (Munksgaard et al., 1999; Fisher et al., 2002). Those studies either prevented cattle from lying (Munksgaard et al., 1999; Fisher et al., 2002) or did not find (Fisher et al., 2003) or report (Tucker et al., 2007; Webster et al., 2008) changes in lying time across days of exposure to wet winter conditions.

Acute stress can also reduce circulating lymphocytes (Davis et al., 2008), which may explain why lower lymphocyte and basophil counts were observed in the current study and in another when cows were exposed to wet winter conditions (Webster et al., 2008). Unexpectedly, the total WBC counts were above the reference range of 4.0 to $12.0 \times 10^{9} / \mathrm{L}$ (Jackson and Cockcroft, 2007) before treatment, and the reasons for this are unclear. Reductions in circulating lymphocyte counts are sometimes interpreted as a sign of immunosuppression (Davis et al., 2008). This, combined with poorer hygiene in muddier conditions, could present an increased risk for infection. Consistent with studies in winter that reported poorer hygiene scores in muddier conditions (Muller et al., 1996; Fisher et al., 2003), as soil moisture levels increased so did the percentage of dirty surface area on the udders, sides, and legs of the cattle in our study. Dirtier udders are associated with subclinical mastitis (Schreiner and Ruegg, 2003), and the mammary glands are particularly susceptible to infection during the dry period (Oliver and Sordillo, 1988). Further study is needed to examine whether increased soil moisture results in higher rates of infection.

\section{Lying Postures, Body Temperature, and Metabolic Response}

When cattle chose to lie down on soil in muddier conditions, they tucked their legs beneath their bodies at least 3 times as often as when the soil was dry. Similar lying postures were observed in winter studies of calves $\left(\mathrm{T} \leq 3^{\circ} \mathrm{C}\right.$; Gonzalez-Jimenez and Blaxter, 1962; Brunsvold et al., 1985) and cows (rainy and windy conditions with mean $\mathrm{T} 5^{\circ} \mathrm{C}$ and wind chill $-10^{\circ} \mathrm{C}$; Tucker et al., 2007), and the latter also showed increased plasma NEFA levels, indicating greater fat metabolism. Lying with the legs bent may be a thermoregulatory strategy, reducing the surface area cattle expose to the air, the ground, or both.

In the current study, however, this posture may have reflected an attempt to reduce contact with mud for other reasons such as avoiding an aversive texture. In support of this concept, when given the choice between wet and dry bedding ( 29 vs. $\geq 81 \% \mathrm{DM}$ ), cows avoided wet bedding not only in winter but also in summer (Keys et al., 1976), when losing heat could be beneficial rather than detrimental. Avoiding heat loss may have been a limited factor in the present study, because conditions were relatively mild. Cattle were protected from wind and rain, and the average minimum air and soil temperatures were approximately 7 and $11^{\circ} \mathrm{C}$, respectively, in all treatments. Because these values are above the performance loss and lower critical temperature thresholds for dry cows $\left(5\right.$ and $-15^{\circ} \mathrm{C}$, respectively; Hahn, 1985), it was not surprising that we observed no treatment differences in average body temperature. We also found no evidence that cattle increased heat production or fat mobilization to counteract heat loss or the additional energy required to walk in mud, because we observed no treatment differences in DMI, time spent feeding, or plasma NEFA levels.

\section{CONCLUSIONS}

Muddy conditions were aversive for cattle and led to reduced lying time and a greater proportion of lying time spent on concrete. Parity affected these responses: 
cows showed a greater reduction in lying time, whereas heifers spent almost all of their lying time on concrete in the muddiest conditions. When cattle chose to lie on muddier soil, they spent a greater proportion of the time with their legs tucked beneath their bodies, reducing the surface area they exposed to their surroundings. Finally, muddier conditions resulted in poorer hygiene on the udder, legs, and sides. Our study demonstrates that wet soil, even in the absence of wind or rain, has negative implications for cattle welfare. This underscores the importance of preventing mud accumulation, for example through drainage, rainwater diversion, and manure management.

\section{ACKNOWLEDGMENTS}

The authors are grateful to those who assisted with data collection: Danielle Affinito, Henry Au, Benjamin DeYoung, John Grima, Amanda Grout, Amanda Hall, Susan Hawkins, Nadège Krebs, Erin Mintline, and Roxanne Robles, all affiliated with UC Davis. Many thanks also to Doug Gisi and Sharlie Folsom of the UC Davis Dairy Teaching and Research Facility; Frank Mitloehner, Daniel Sehnert, and the Animal Science Farm Crew; the UC Davis feedlot; and the United States Department of Agriculture multi-state research project NC1029 (Washington, DC). We gratefully acknowledge the infrastructure support of the Department of Animal Science, College of Agricultural and Environmental Sciences, and the UC Davis California Agricultural Experiment Station.

\section{REFERENCES}

Bolinger, D. J., J. L. Albright, J. Morrow-Tesch, S. J. Kenyon, and M. D. Cunningham. 1997. The effects of restraint using self-locking stanchions on dairy cows in relation to behavior, feed intake, physiological parameters, health, and milk yield. J. Dairy Sci. 80:24112417. https://doi.org/10.3168/jds.S0022-0302(97)76193-9.

Borderas, T. F., B. Pawluczuk, A. M. de Passillé, and J. Rushen. 2004 Claw hardness of dairy cows: Relationship to water content and claw lesions. J. Dairy Sci. 87:2085-2093. https://doi.org/10.3168/ jds.S0022-0302(04)70026-0.

Brunsvold, R., C. Cramer, and H. Larsen. 1985. Behavior of dairy calves reared in hutches as affected by temperature. Trans. ASAE 28:1265-1268. https://doi.org/10.13031/2013.32422.

Davis, A., D. Maney, and J. Maerz. 2008. The use of leukocyte profiles to measure stress in vertebrates: A review for ecologists. Funct. Ecol. 22:760-772. https://doi.org/10.1111/j.1365-2435.2008.01467.x.

Degen, A. A., and B. A. Young. 1993. Rate of metabolic heat production and rectal temperature of steers exposed to simulated mud and rain conditions. Can. J. Anim. Sci. 73:207-210. https://doi. org/10.4141/cjas93-021.

Dijkman, J., and P. Lawrence. 1997. The energy expenditure of cattle and buffaloes walking and working in different soil conditions. J. Agric. Sci. 128:95-103.

Endres, M. I., and A. E. Barberg. 2007. Behavior of dairy cows in an alternative bedded-pack housing system. J. Dairy Sci. 90:41924200. https://doi.org/10.3168/jds.2006-751.
Endres, M. I., T. J. DeVries, M. A. G. von Keyserlingk, and D. M. Weary. 2005. Short communication: Effect of feed barrier design on the behavior of loose-housed lactating dairy cows. J. Dairy Sci. 88:2377-2380. https://doi.org/10.3168/jds.S0022-0302(05)729155.

Ferguson, J. O., D. T. Galligan, and N. Thomsen. 1994. Principal descriptors of body condition score in Holstein cows. J. Dairy Sci. 77:2695-2703. https://doi.org/10.3168/jds.S0022-0302(94)77212$\mathrm{X}$.

Fisher, A. D., M. Stewart, G. A. Verkerk, C. J. Morrow, and L. R. Matthews. 2003. The effects of surface type on lying behaviour and stress responses of dairy cows during periodic weather-induced removal from pasture. Appl. Anim. Behav. Sci. 81:1-11. https:// doi.org/10.1016/S0168-1591(02)00240-X.

Fisher, A. D., G. A. Verkerk, C. J. Morrow, and L. R. Matthews. 2002. The effects of feed restriction and lying deprivation on pituitary-adrenal axis regulation in lactating cows. Livest. Prod. Sci 73:255-263. https://doi.org/10.1016/S0301-6226(01)00246-9.

Fitzgerald, T., B. W. Norton, R. Elliott, H. Podlich, and O. L. Svendsen. 2000. The influence of long-term supplementation with biotin on the prevention of lameness in pasture fed dairy cows. J. Dairy Sci. 83:338-344. https://doi.org/10.3168/jds.S00220302(00)74884-3.

Fox, D. G., and T. P. Tylutki. 1998. Accounting for the effects of environment on the nutrient requirements of dairy cattle. J. Dairy Sci. 81:3085-3095. https://doi.org/10.3168/jds.S0022-0302(98)75873-

Fregonesi, J. A., and J. D. Leaver. 2002. Influence of space allowance and milk yield level on behaviour, performance and health of dairy cows housed in strawyard and cubicle systems. Livest. Prod. Sci. 78:245-257. https://doi.org/10.1016/S0301-6226(02)00097-0.

Fregonesi, J. A., D. M. Veira, M. A. G. von Keyserlingk, and D. M. Weary. 2007. Effects of bedding quality on lying behavior of dairy cows. J. Dairy Sci. 90:5468-5472. https://doi.org/10.3168/ jds.2007-0494.

Gonzalez-Jimenez, E., and K. Blaxter. 1962. The metabolism and thermal regulation of calves in the first month of life. Br. J. Nutr. 16:199-212. https://doi.org/10.1079/BJN19620021.

Hahn, G. L. 1985. Management and housing of farm animals in hot environments. Pages 151-174 in Stress Physiology of Livestock. Vol. II: Ungulates. M. K. Yousef, ed. CRC Press, Inc., Boca Raton, FL.

Haley, D. B., A. M. de Passillé, and J. Rushen. 2001. Assessing cow comfort: Effects of two floor types and two tie stall designs on the behaviour of lactating dairy cows. Appl. Anim. Behav. Sci. 71:105-117. https://doi.org/10.1016/S0168-1591(00)00175-1.

Haley, D. B., J. Rushen, and A. M. de Passillé. 2000. Behavioural indicators of cow comfort: Activity and resting behaviour of dairy cows in two types of housing. Can. J. Anim. Sci. 80:257-263. https://doi.org/10.4141/A99-084.

Heckner, F., H. P. Lehmann, and Y. S. Kao. 1988. Practical Microscopic Hematology: A Manual for the Clinical Laboratory and Clinical Practice. Urban and Schwarzenberg, Baltimore, MD.

Jackson, P. G. G., and P. D. Cockcroft. 2007. Appendix 2: Laboratory reference values: Haematology. Page 302 in Clinical Examination of Farm Animals. Blackwell Science Ltd., Hoboken, NJ.

Jensen, M. B., L. Munksgaard, L. J. Pedersen, J. Ladewig, and L. Matthews. 2004. Prior deprivation and reward duration affect the demand function for rest in dairy heifers. Appl. Anim. Behav. Sci 88:1-11. https://doi.org/10.1016/j.applanim.2004.02.019.

Jensen, M. B., L. J. Pedersen, and L. Munksgaard. 2005. The effect of reward duration on demand functions for rest in dairy heifers and lying requirements as measured by demand functions. Appl. Anim. Behav. Sci. 90:207-217. https://doi.org/10.1016/j. applanim.2004.08.006.

Kelly, C. F., and T. E. Bond. 1971. Bioclimatic factors and their measurement. Pages 7-92 in A Guide to Environmental Research on Animals. National Research Council, ed. National Academies Press, Washington, DC

Keys, J. E., L. W. Smith, and B. T. Weinland. 1976. Response of dairy cattle given a free choice of free stall location and three bedding 
materials. J. Dairy Sci. 59:1157-1162. https://doi.org/10.3168/jds. S0022-0302(76)84337-8.

Krohn, C. C., and L. Munksgaard. 1993. Behaviour of dairy cows kept in extensive (loose housing/pasture) or intensive (tie stall) environments. II. Lying and lying-down behaviour. Appl. Anim. Behav. Sci. 37:1-16. https://doi.org/10.1016/0168-1591(93)90066-X.

Ledgerwood, D. N., C. Winckler, and C. B. Tucker. 2010. Evaluation of data loggers, sampling intervals, and editing techniques for measuring the lying behavior of dairy cattle. J. Dairy Sci. 93:51295139. https://doi.org/10.3168/jds.2009-2945.

Metz, J. H. M. 1985. The reaction of cows to a short-term deprivation of lying. Appl. Anim. Behav. Sci. 13:301-307. https://doi. org/10.1016/0168-1591(85)90010-3.

Muller, C. J. C., J. A. Botha, and W. A. Smith. 1996. Effect of confinement area on production, physiological parameters and behaviour of Friesian cows during winter in a temperate climate. S. Afr. J. Anim. Sci. 26:1-5.

Munksgaard, L., K. L. Ingvartsen, L. J. Pedersen, and V. K. M. Nielsen. 1999. Deprivation of lying down affects behaviour and pituitaryadrenal axis responses in young bulls. Acta Agric. Scand. A. Anim. Sci. 49:172-178. https://doi.org/10.1080/090647099424088.

Munksgaard, L., M. B. Jensen, L. J. Pedersen, S. W. Hansen, and L. Matthews. 2005. Quantifying behavioural priorities-Effects of time constraints on behaviour of dairy cows, Bos taurus. Appl. Anim. Behav. Sci. 92:3-14. https://doi.org/10.1016/j. applanim.2004.11.005.

National Milk Producers Federation. 2013. National Dairy FARM Program Animal Care Reference Manual. National Milk Producers Federation, Arlington, VA.

Oliver, S. P., and L. M. Sordillo. 1988. Udder health in the periparturient period. J. Dairy Sci. 71:2584-2606. https://doi.org/10.3168/ jds.S0022-0302(88)79847-1.

Phillips, C. J. C., and I. D. Morris. 2001. A novel operant conditioning test to determine whether dairy cows dislike passageways that are dark or covered with excreta. Anim. Welf. 10:65-72.

Phillips, C. J. C., and I. D. Morris. 2002. The ability of cattle to distinguish between, and their preference for, floors with different levels of friction, and their avoidance of floors contaminated with excreta. Anim. Welf. 11:21-29.

Reich, L. J., D. M. Weary, D. M. Veira, and M. A. G. von Keyserlingk. 2010. Effects of sawdust bedding dry matter on lying behavior of dairy cows: A dose-dependent response. J. Dairy Sci. 93:15611565. https://doi.org/10.3168/jds.2009-2713.

Reneau, J. K., A. J. Seykora, B. J. Heins, M. I. Endres, R. J. Farnsworth, and R. F. Bey. 2005. Association between hygiene scores and somatic cell scores in dairy cattle. J. Am. Vet. Med. Assoc. 227:1297-1301. https://doi.org/10.2460/javma.2005.227.1297.

Rodríguez-Lainz, A., D. W. Hird, T. E. Carpenter, and D. H. Read. 1996. Case-control study of papillomatous digital dermatitis in southern California dairy farms. Prev. Vet. Med. 28:117-131. https://doi.org/10.1016/0167-5877(96)01024-0.

Rushen, J., D. Haley, and A. M. de Passillé. 2007. Effect of softer flooring in tie stalls on resting behavior and leg injuries of lactating cows. J. Dairy Sci. 90:3647-3651. https://doi.org/10.3168/ jds.2006-463.
SAS Institute Inc. 2014. SAS/STAT 13.2 User's Guide. SAS Institute Inc., Cary, NC.

Schreiner, D. A., and P. L. Ruegg. 2003. Relationship between udder and leg hygiene scores and subclinical mastitis. J. Dairy Sci. 86:3460-3465. https://doi.org/10.3168/jds.S0022-0302(03)739502.

Schütz, K. E., K. V. Clark, N. R. Cox, L. R. Matthews, and C. B. Tucker. 2010. Responses to short-term exposure to simulated rain and wind by dairy cattle: Time budgets, shelter use, body temperature and feed intake. Anim. Welf. 19:375-383.

Schütz, K. E., and N. R. Cox. 2014. Effects of short-term repeated exposure to different flooring surfaces on the behavior and physiology of dairy cattle. J. Dairy Sci. 97:2753-2762. https://doi. org/10.3168/jds.2013-7310.

Somers, J. G. C. J., K. Frankena, E. N. Noordhuizen-Stassen, and J. H. M. Metz. 2003. Prevalence of claw disorders in Dutch dairy cows exposed to several floor systems. J. Dairy Sci. 86:2082-2093. https://doi.org/10.3168/jds.S0022-0302(03)73797-7.

Stull, C. L., L. L. McV. Messam, C. A. Collar, N. G. Peterson, A. R. Castillo, B. A. Reed, K. L. Andersen, and W. R. VerBoort. 2008. Precipitation and temperature effects on mortality and lactation parameters of dairy cattle in California. J. Dairy Sci. 91:4579 4591. https://doi.org/10.3168/jds.2008-1215.

Tucker, C. B., D. Fraser, and D. M. Weary. 2001. Tail docking dairy cattle: Effects on cow cleanliness and udder health. J. Dairy Sci. 84:84-87. https://doi.org/10.3168/jds.S0022-0302(01)74455-4.

Tucker, C. B., A. R. Rogers, G. A. Verkerk, P. E. Kendall, J. R. Webster, and L. R. Matthews. 2007. Effects of shelter and body condition on the behaviour and physiology of dairy cattle in winter. Appl. Anim. Behav. Sci. 105:1-13. https://doi.org/10.1016/j. applanim.2006.06.009.

USDA. 2010. Facility Characteristics and Cow Comfort on U.S. Dairy Operations, 2007. UDSA-Animal and Plant Health Inspection Service-Veterinary Services, Centers for Epidemiology and Animal Health, Fort Collins, CO.

USDA. 2016. Dairy Cattle Management Practices in the United States, 2014. UDSA-Animal and Plant Health Inspection ServiceVeterinary Services, Centers for Epidemiology and Animal Health, Fort Collins, CO.

Vanegas, J., M. Overton, S. L. Berry, and W. M. Sischo. 2006. Effect of rubber flooring on claw health in lactating dairy cows housed in free-stall barns. J. Dairy Sci. 89:4251-4258. https://doi. org/10.3168/jds.S0022-0302(06)72471-7.

Vermunt, J. J., and P. R. Greenough. 1996. Sole haemorrhages in dairy heifers managed under different underfoot and environmental conditions. Br. Vet. J. 152:57-73. https://doi.org/10.1016/ S0007-1935(96)80086-8.

Webster, J. R., M. Stewart, A. R. Rogers, and G. A. Verkerk. 2008. Assessment of welfare from physiological and behavioural responses of New Zealand dairy cows exposed to cold and wet conditions. Anim. Welf. 17:19-26.

Welfare Quality. 2009. Welfare Quality Assessment Protocol for Cattle. Welfare Quality Consortium, Lelystad, Netherlands. 